\title{
Tożsamość rodziny jako prawo indywidualno-kolektywne w ujęciu socjologiczno-prawnym
}

Pojęcie tożsamości jest złożone i inaczej definiowane w prawie, inaczej w socjologii, a jeszcze inaczej w antropologii. Również samo słowo „tożsamość” ma wiele znaczeń i inaczej używa się go w życiu codziennym, a inaczej definiowane jest przez naukowców. W powszechnym odbiorze słowo „tożsamość” odzwierciedla wartości, wierzenia kodeks postępowania jednostki. Oznacza także przynależność etniczną, religijną czy narodową. Etymologia polskiego słowa „tożsamość” wbrew pozorom nie odbiega od jego znaczenia w innych językach ${ }^{1}$ - „tożsamość” bowiem to identyczność 2 .

Tożsamość jest zatem podjęciem złożonym. To z jednej strony najważniejszy element psychiczny rozwoju człowieka, ale można także mówić o tożsamości organizacji, tożsamości grupy społecznej czy o tożsamości narodu lub grupy etnicznej. Oprócz określenia grupy, która ma tożsamość,

W większości języków europejskich słowo „tożsamość” pochodzi od łacińskiego słowa identitās znaczącego "taki sam, identyczny”. Przeszło ono do języka francuskiego, a z niego do języka angielskiego (identity).

2 Tożsamość, w: Słownik języka polskiego PWN, https://sjp.pwn.pl/sjp/to\%C5\%BCsamo\%C5\%9B\%C4\%87;2530211 (04.06.2020). 
opisuje się ją jako tożsamość zbiorową, indywidualną, etniczną, polityczną czy tożsamość społeczną. Jest to przykładowe wyliczenie, nie ma jednak charakteru zamkniętego katalogu. Można powiedzieć, iż tożsamość nie ma granic ani jednorodnego znaczenia. Jak napisał Florian Coulmas, kategoria ta jako idea, która pojawiła się w określonym czasie i przestrzeni, jest tworem zachodnich nauk socjologicznych ${ }^{3}$. W nauce wyróżnia się podejście prymordialistyczne, konstruktywistyczne i modernistyczne postrzegając tożsamość w ujęciu grupowym i indywidualnym. Teoria prymordialistyczna definiuje tożsamość jako zbiór indywidualnych i grupowych, biologicznie dziedziczonych cech lub wyćwiczonych zachowań i kulturowej odmienności. Harold Isaacs uznał tożsamość etniczną jednostki za podstawową tożsamość grupy, bowiem jest ona dla niego cech, które człowiek posiada od urodzenia jako członek określonej rodziny, żyjący w danym czasie i miejscu. Isaacs reprezentuje prymordializm w wersji najbardziej skrajnej, w której religia została ujęta jako podstawowy jej element. Niemniej jednak nie jest ona elementem stałym - niektórzy ludzie doświadczają zmiany tożsamości, która następuje intencjonalnie w ciągu procesu ich życia ${ }^{4}$. Jako jeden z najważniejszych elementów rozwoju człowieka pozwala ona zatem jednostce na wykształcenie własnego systemu wartości oraz zasad moralnych, którymi dana osoba będzie kierowała się w życiu 5 . W kontekście psychologiczno-społecznym tożsamość indywidualna jest odzwierciedleniem wewnętrznego ,ja" człowieka.

Co zatem tworzy tożsamość? Czym ona jest? Prymordializm widział źródło tożsamości narodowej, społecznej i etnicznej w pochodzeniu człowieka i środowisku kulturowym, w którym się on urodził. Teoria przypadkowości (ang. circumstantialism) uznała ją za efekt użyteczności, twór polityczny ${ }^{6}$. Niemniej jednak nie posiadamy jednej tylko tożsamości, a tożsamość narodowa jest efektem końcowym złożonego procesu odnajdywania się człowieka w określonej grupie społecznej. W starożytności ludzie poszukiwali swojego pochodzenia poprzez odkrycie na nowo swojej kultury i historii. Ta tożsamość kulturowa pozwalała jednak wyłącznie na podkreślenie swojej

\footnotetext{
F. Coulmas, Identity: A Very Short Introduction, Oxford 2019, s. 1-5.

S. Comell, D. Hartmann, Ethnicity and Race: Making Identities, Thousand Oaks 2007, s. 52-54.

5 D. Kuźnicka, Prawo do tożsamości jako prawo dziecka - wybrane zagadnienia, „Folia Iuridica Universitatis Wratislaviensis" (2016), vol 5 (2), s. 181.

$6 \quad$ S. Cornell, D. Hartmann, Ethnicity and Race, s. 70-73.
} 
odmienności w stosunku do innych, jednak nie umiała wykazać istnienia poczucia przynależności do określonej, tożsamej kulturowo grupy. Dopiero tożsamość etniczna umiała zapewnić istnienie tego związku?

Społeczno-prawna analiza miejsca człowieka w społeczności podkreśla, iż najważniejsza dla jego rozwoju jest jego tożsamość etniczno-narodowa, której źródłem jest tożsamość jego rodziny. Tożsamość narodowa to przynależność do większej grupy, tożsamość narodu powiązana jest jednak $\mathrm{z}$ tożsamością etniczną, a ta nie może istnieć bez rodziny. Anthony Smith wskazał, że sercem narodu jest jego pochodzenie etniczne ${ }^{8}$, a Ernest Renan podkreślił, iż istnienie narodu jest „,codziennym plebiscytem”, a idea narodu podlega naszym nieustanym wyborom ${ }^{9}$. Według prymordializmu tożsamość narodowa jest bezpośrednio wyprowadzana z grupy etnicznej, która ją tworzy. Naród posiada swoje źródło w historii - istniał od zawsze, a jego członków łączy poczucie wspólnej historii i przynależności do narodu.

Sercem każdego narodu jest rodzina. Modernistyczna krytyka prymordializmu rozumie tworzenie tożsamości narodu jako celowe działanie administracyjne państwa, neguje zatem istnienie jednej tożsamości narodowej, wskazując, iż może ona zawierać tożsamość religijną i przynależnościową. Benedict Anderson wskazał, iż tożsamość narodowa jest wyimaginowanym obrazem silnych sentymentalnych węzłów łączonych ludzi. Naród to wymyślona wspólnota, bowiem jej członkowie w ogóle się nie znają ${ }^{10}$. Eric Hobsbawm z kolei wskazał, iż tożsamość narodowa jest narzędziem wymyślonym przez polityczne elity ${ }^{11}$. Hobsbawm i Ernest Gellner uznawali ją za efekt nacjonalizmu ${ }^{12}$, jednak dla Gellnera jest ona efektem dwóch powiązanych czynników: woli społeczeństwa (ludzi) i rozpowszechnienia się społecznego porządku nazwanego przez niego „wysoką kulturą”. Sarah

7 E. S. Gruen, Introduction, w: Cultural Identity in Ancient Mediterranean, ed. E. S. Gruen, Los Angeles 2011, s. 1-4.

8 A. Smith, The State of the Nation. Ernest Gellner and the Theory of Nationalism, ed. by J. A. Hall, Cambridge1998, s. 6.

9 R. McClain Chadbourne, Ernest Renan, New York 1968.

10 B. R. O'Gorman Anderson, Imagined Communities: Reflections on the Origin and Spread of Nationalism, London 2006, s. 5-7.

11 E. J. Hobsbawm, Nations and Nationalism Since 1780: Programme, Myth, Reality, Cambridge 2012, s. 176-178.

12 A.J. Bellami, The Formation of Croatian National Identity: A Centuries-old Dream?, Manchester 2003, New York: Manchester University, http://www.jstor.org/stable/j.ctt155jgdc (24.09.2020). 
Radcliffe i Sally Westwood z kolei tożsamość narodową wywodzą z czterech elementów: wyobrażenia jednostki o narodzie, ucieleśnienia narodu, życia $\mathrm{w}$ narodzie i umiejscowienia siebie w narodzie. Wszystkie one poprzez relację, jaka istnieje między jego podmiotami, budują tożsamość narodową. Katherine Verdery słusznie wskazuje, iż tożsamość narodowa tworzy się na dwóch płaszczyznach: osobistej (nasze wewnętrzne poczucie przynależności narodowej) i społecznej (kolektywne poczucie przynależności do większej grupy) ${ }^{13}$.

Podsumowując powyższe rozważania, za najbardziej prawidłowe należy uznać podejście mieszane, z jednej strony uznające fakt, iż tożsamość człowieka kształtuje się w rodzinie, w której się on wychowuje, z drugiej strony podkreślające, jak wielki wpływ na tożsamość jednostki mają środowisko, w którym ona żyje, jej otoczenie, szkoła, do której uczęszcza, czy miejsce pracy.

Obok tożsamości narodowej dla jednostki ważna jest także tożsamość etniczna. Samo słowo „etniczny” pochodzi od greckiego słowa ethnos i znaczy „naród”, jednakże łacińskie znaczenie tego słowa to „inny”, ten, który nie podziela dominującej wiary, cech, kultury czy zwyczajów. Max Weber napisał, iż grupami etnicznymi powinno się nazywać te grupy ludzi, które wskazują na swoje pochodzenie od wspólnego przodka ze względu na swoje fizyczne podobieństwo, kulturę i tradycję. Więzy etniczne to zatem więzy krwi wspólnego pochodzenie, więzy wspólnych zwyczajów i wspólnej tradycji ${ }^{14}$. Pochodzenie etniczne jest zatem tym, co identyfikuje człowieka najbardziej, odróżnia go od innych.

Eric Hobsbawm słusznie wskazał, iż nie można zrozumieć narodu, grupy etnicznej czy społeczeństwa bez zrozumienia i analizy tego, co „leży poniżej”, czyli zwyczajnych ludzi, bowiem tożsamość człowieka, tożsamość jednostki tworzy się w rodzinie. Biorąc to założenie za punkt wyjścia do podstawowej analizy etniczności, Rogers Brubaker wskazał, iż istnieje nieprawidłowa tendencja do grupowania ludzi ze względu na cechy, jakie im się odgórnie przyzna. Pozwoliło mu to na sformułowanie tezy, iż istnieje możliwość analizowania etniczności bez potrzeby dzielenia ludzi na grupy i tworzenia

13 A. J. Bellamy, The Formation of Croatian National Identity: A Centuries-old Dream, dz. cyt., s. $10-15,27$.

14 S. Cornell, D. Hartmann, Ethnicity and Race, dz. cyt. s. 15-20. 
sztucznych grup społecznych ${ }^{15}$. Tożsamość człowieka, jak wykazano powyżej, zależna jest bowiem od jego pochodzenia rodzinnego. To są właśnie najsilniejsze węzły - nie tylko z punktu widzenia prawnego, ale i społecznego.

Prawo do tożsamości jest jednym z najważniejszych praw współczesnego społeczeństwa. Wydaje się zatem, iż słusznie prawo do tożsamości zostało zapisie w artykule 8 Konwencji o prawach dziecka ${ }^{16}$, jednak sam dokument nie definiuje słowa „tożsamość” i można je dookreślić jako prawo do posiadania własnego imienia i nazwiska, prawo do bycia zidentyfikowanym w systemie państwa, prawo do poznania swoich rodziców i pozostania po ich opieką czy jako prawo do posiadania obywatelstwa wyłącznie poprzez pogłębioną analizę artykułu $7^{17}$ Konwencji ${ }^{18}$. Tożsamość jest zatem zbiorem otwartym, który wypełnia się elementami określającymi człowieka jako jednostkę. Prawo do tożsamości to także prawo do posiadania rodziny i kultu$\mathrm{ry}^{19}$. Dziecko ma zatem prawo do tożsamości rodzinnej, czyli do poznania

15 R. Brubaker, Ethnicity without Groups, Cambridge 2004, s. 1-3.

16 Art. 8: „1. Państwa-Strony podejmują działania mające na celu poszanowanie prawa dziecka do zachowania jego tożsamości, w tym obywatelstwa, nazwiska, stosunków rodzinnych, zgodnych $\mathrm{z}$ prawem, $\mathrm{z}$ wyłączeniem bezprawnych ingerencji. 2 . W przypadku gdy dziecko zostało bezprawnie pozbawione części lub wszystkich elementów swojej tożsamości, Państwa-Strony okażą właściwą pomoc i ochronę w celu jak najszybszego przywrócenia jego tożsamości”. Konwencja o prawach dziecka przyjęta przez Zgromadzenie Ogólne Narodów Zjednoczonych dnia 20 listopada 1989 r., Dz. U. z 1991, poz. 120, nr 526.

17 Art. 7: 1. „Niezwłocznie po urodzeniu dziecka zostanie sporządzony jego akt urodzenia, a dziecko od momentu urodzenia będzie miało prawo do otrzymania imienia, uzyskania obywatelstwa oraz, jeśli to możliwe, prawo do poznania swoich rodziców i pozostawania pod ich opieką. 2. Państwa-Strony zapewnią, aby te prawa stały się zgodne z ich prawem wewnętrznym oraz z ich międzynarodowymi zobowiązaniami w tej dziedzinie, w szczególności w przypadkach, gdyby brak tych uregulowań spowodował, iż dziecko zostałoby bezpaństwowcem”. Konwencja o prawach dziecka przyjęta przez Zgromadzenie Ogólne Narodów Zjednoczonych dnia 20 listopada 1989 r., Dz. U. z 1991, poz. 120, nr 526.

18 Art. 7. Konwencja o prawach dziecka przyjęta przez Zgromadzenie Ogólne Narodów Zjednoczonych dnia 20 listopada 1989 r., Dz. U. z 1991, poz. 120, nr 526.

19 Artykuł 23: „Rodzina jest naturalną i podstawową komórką społeczeństwa i ma prawo do ochrony ze strony społeczeństwa i Państwa. 2. Uznaje się prawo mężczyzn i kobiet w wieku małżeńskim do zawarcia małżeństwa i założenia rodziny. 3. Żaden związek małżeński nie może być zawarty bez swobodnie wyrażonej i pełnej zgody przyszłych małżonków. 4. Państwa-Strony niniejszego Paktu podejmą odpowiednie kroki w celu zapewnienia równych praw i obowiązków małżonków w odniesieniu do zawarcia małżeństwa, podczas jego trwania i przy jego rozwiązaniu. W przypadku rozwiązania małżeństwa należy podjąć środki w celu zapewnienia dzieciom niezbędnej ochrony”. Artykuł 24: 1. „Każde dziecko, bez żadnej dyskryminacji ze względu na rasę, kolor skóry, płeć, język, religię, pochodzenie narodowe lub społeczne, sytuację majątkową lub urodzenie, ma prawo do środków ochrony, jakich 
swojego etnicznego pochodzenia, swojej rodziny biologicznej, a tym samym swojej tożsamości etnicznej. Tożsamość rodzinna (family identity) pozostaje zatem prawem dziecka, a obowiązkiem państwa jest umożliwienie dziecku poznania jego etnicznych korzeni ${ }^{20}$.

Rodzi się jednak pytanie: skoro dziecko ma prawo do tożsamości etnicznej, czy rodzice mają prawo do wychowania go zgodnie z swoim pochodzeniem etnicznym? Przyjmując za prawidłowe stanowisko Brubarkera, iż naród, społeczność należy badać od ich źródeł, od tej najmniejszej grupy społecznej, jaką jest rodzina, bez założenia, iż jest ona częścią większej grupy, rodzinie należy przyznać prawo do wychowania dziecka zgodnie z tożsamością rodziny. Rodzina bowiem posiada swoją tożsamość, która charakteryzuje się zwyczajami, kulturą czy nawet specjalnym słownictwem i charakterystycznymi powiedzeniami. Tożsamość rodziny to także jej wspólne pochodzenie i tradycja kultura. Niemniej jednak takie ogóle prawo rodziny do wychowania dziecka zgodnie z własną tożsamością zostało wprost przyznane wyłącznie mniejszościom etnicznym i narodowym. Prawodawca polski dokonał zatem podziału i pogrupowania obywateli na tych wykazujących etniczną przynależność do Narodu Polskiego oraz tych, którzy należą do mniejszości. Artykuł 35 Konstytucji Rzeczypospolitej Polskiej ${ }^{21}$ przyznał obywatelom polskim należącym do mniejszości narodowych i etnicznych wolność zachowania i rozwoju własnego języka i kultury, zachowania obyczajów i tradycji. Dodatkowo zagwarantował mniejszościom narodowym i etnicznym prawo do tworzenia własnych instytucji edukacyjnych i kulturalnych oraz instytucji służących ochronie tożsamości religijnej, a także prawo do uczestnictwa w rozstrzyganiu spraw

wymaga status małoletniego, ze strony rodziny, społeczeństwa i Państwa. 2. Każde dziecko powinno być zarejestrowane niezwłocznie po urodzeniu i posiadać nazwisko. 3. Każde dziecko ma prawo do nabycia obywatelstwa”. Art. 23 i art. 24, Międzynarodowego Paktu Praw Obywatelskich i Politycznych, Dz. U. 1977, nr 38, poz. 167.

20 G. Stewart, Interpreting the Child's Right to Identity in the U.N. Convention on the Rights of the Child, „Family Law Quarterly” 3 (1992) 26, s. 221-233, www.jstor.org/stable/25739908 (04.06.2020).

21 Art. 35: „Rzeczpospolita Polska zapewnia obywatelom polskim należącym do mniejszości narodowych i etnicznych wolność zachowania i rozwoju własnego języka, zachowania obyczajów i tradycji oraz rozwoju własnej kultury. 2. Mniejszości narodowe i etniczne mają prawo do tworzenia własnych instytucji edukacyjnych, kulturalnych i instytucji służących ochronie tożsamości religijnej oraz do uczestnictwa w rozstrzyganiu spraw dotyczących ich tożsamości kulturowej”. Konstytucja Rzeczypospolitej Polskiej z dnia 2 kwietnia 1997 r.. Dz. U. z 1997, poz. 78, nr 483. 
dotyczących ich tożsamości kulturowej ${ }^{22}$. Dodatkowo ustawa o mniejszościach narodowych i etnicznych ${ }^{23}$, która oprócz zdefiniowania samych grup daje mniejszościom możliwość używania ich języka jako pomocniczego przed organami gminy, a także możliwość używania obok urzędowych nazw miejscowości i obiektów fizjograficznych oraz nazw ulic dodatkowych tradycyjnych nazw w języku mniejszości. Ustawa nakazuje także organom władzy publicznej podejmowanie odpowiednich środków w celu wspierania działalności zmierzającej do ochrony, zachowania i rozwoju tożsamości kulturowej mniejszości ${ }^{24}$. Ustawodawca polski zagwarantował zatem swoim obywatelom prawo do tożsamości etnicznej jako prawo ogólne, należne jedynie wyraźnie zdefiniowanej w ustawie grupie ${ }^{25}$. Nie ulega wątpliwości, iż w rozumieniu ustawodawcy polskiego tożsamość etniczna jest prawem grupowym, prawem kolektywnym, tożsamością kolektywną. Nie jest jednak

22 Art. 35, Konstytucja Rzeczypospolitej Polskiej z dnia 2 kwietnia 1997 r.. Dz. U. z 1997, poz. 78, nr 483.

23 Ustawa z dnia 6 stycznia 2005 r. o mniejszościach narodowych i etnicznych oraz o języku regionalnym, Dz. U. z 2017, nr 823 t.j.

24 Ustawa z dnia 6 stycznia 2005 r. o mniejszościach narodowych i etnicznych oraz o języku regionalnym, Dz. U. z 2017, nr 823 t.j.

25 Ustawodawca zdefiniował bardzo kazuistyczne trzy grupy społeczne, które mają przyznane określone prawa w Rzeczpospolitej Polskiej: Naród Polski jako pojęcie bardzo ogóle w rozumieniu politycznym i etnicznym, mniejszości narodowe oraz mniejszości etniczne. W art. 2 czytamy, iż „1. Mniejszością narodową, w rozumieniu ustawy, jest grupa obywateli polskich, która spełnia łącznie następujące warunki: 1) jest mniej liczebna od pozostałej części ludności Rzeczypospolitej Polskiej; 2) w sposób istotny odróżnia się od pozostałych obywateli językiem, kulturą lub tradycją; 3) dąży do zachowania swojego języka, kultury lub tradycji; 4) ma świadomość własnej historycznej wspólnoty narodowej i jest ukierunkowana na jej wyrażanie i ochronę; 5) jej przodkowie zamieszkiwali obecne terytorium Rzeczypospolitej Polskiej od co najmniej 100 lat; 6) utożsamia się z narodem zorganizowanym we własnym państwie. 2. Za mniejszości narodowe uznaje się następujące mniejszości: 1) białoruską; 2) czeską; 3) litewską; 4) niemiecką; 5) ormiańską; 6) rosyjską; 7) słowacką; 8) ukraińską; 9) żydowską. 3. Mniejszością etniczną, w rozumieniu ustawy, jest grupa obywateli polskich, która spełnia łącznie następujące warunki: 1) jest mniej liczebna od pozostałej części ludności Rzeczypospolitej Polskiej; 2) w sposób istotny odróżnia się od pozostałych obywateli językiem, kulturą lub tradycją; 3) dąży do zachowania swojego języka, kultury lub tradycji; 4) ma świadomość własnej historycznej wspólnoty etnicznej i jest ukierunkowana na jej wyrażanie i ochronę; 5) jej przodkowie zamieszkiwali obecne terytorium Rzeczypospolitej Polskiej od co najmniej 100 lat; 6) nie utożsamia się z narodem zorganizowanym we własnym państwie. 4. Za mniejszości etniczne uznaje się następujące mniejszości: 1) karaimską; 2) łemkowską; 3) romską; 4) tatarską”. Art. 2, Ustawa z dnia 6 stycznia 2005 r. o mniejszościach narodowych i etnicznych oraz o języku regionalnym, Dz. U. z 2017, nr 823 t.j. 
prawem indywidualnym, niezależnym od przynależności do określonej grupy społecznej. Wydaje się to wadą polskiego systemu prawnego, który z jednej strony rozpoznaje istnienie prawa do tożsamości dziecka, grupy etnicznej czy narodowej, a nie przyznaje tego prawa w ogólnym charakterze rodzinie. Prawo to oczywiście można wyinterpretować z innych aktów prawnych, jednak rodzinie nie jest ono nigdzie przypisane wprost. Wydaje się, iż prawo do tożsamości rodziny nie powinno być wyłącznie prawem kolektywnym, ale przede wszystkim prawem indywidualno-kolektywnym, przynależnym każdej rodzinie, która wspólne z państwem wychowuje nowego członka danej społeczności. Państwo powinno zatem zagwarantować rodzinie prawo do jej wewnętrznej tożsamości.

Niemniej jednak należy się zgodzić ze stwierdzeniem, iż prawo rodziny do tożsamości jest prawem abstrakcyjnym, po części objętym ochroną z artykułu 8 Konwencji o ochronie praw człowieka i podstawowych wolności ${ }^{26}$, zgodnie z którym każdy ma prawo do poszanowania swojego życia rodzinnego i życia prywatnego. Pojęcia te są na tyle ogólne, iż zawierają w sobie ochronę relacji pomiędzy członkami rodziny, związku uczuciowego, jaki między nimi zachodzi. Orzecznictwo Europejskiego Trybunału Sprawiedliwości wskazuje bardziej na indywidualny charakter tych praw jako wyłącznie związanych z jednostką. W dokumentach bardzo rzadko pojawia się odniesienie do praw rodziny jako nośnika prawa do tożsamości ${ }^{27}$.

Powraca zatem pytanie, czy tożsamość rodziny ma prawo do ochrony w porządku prawnym? Rodzina jest najważniejszą jednostką społeczną każdej społeczności i państwo powinno objąć ją swoją szczególną ochroną. Jej tożsamość zaś jest tym, co stanowi o jej wyjątkowości i przekłada się na tożsamość grupy etnicznej i tożsamość całego narodu, a tym samym na tożsamość państwa. Ustawodawca zatem wybiórczo objął ochroną tożsamość

26 „1. Każdy ma prawo do poszanowania swojego życia prywatnego i rodzinnego, swojego mieszkania i swojej korespondencji. 2. Niedopuszczalna jest ingerencja władzy publicznej w korzystanie $\mathrm{z}$ tego prawa, $\mathrm{z}$ wyjątkiem przypadków przewidzianych przez ustawę i koniecznych $\mathrm{w}$ demokratycznym społeczeństwie $\mathrm{z}$ uwagi na bezpieczeństwo państwowe, bezpieczeństwo publiczne lub dobrobyt gospodarczy kraju, ochronę porządku i zapobieganie przestępstwom, ochronę zdrowia i moralności lub ochronę praw i wolności innych osób”. Art. 8 Konwencja o ochronie praw człowieka i podstawowych wolności sporządzona w Rzymie dnia 4 listopada 1950 r., zmieniona następnie Protokołami nr 3, 5 i 8 oraz uzupełniona Protokołem nr 2, Dz. U. z 1993, poz. 61, nr 284.

27 I. Roagna, Ochrona praw do poszanowania życia prywatnego w Europejskiej Konwencji o Ochronie Praw Człowieka, Strasburg 2012, s. 17-22. 
grup etnicznych czy tożsamość narodu, pomijając tożsamość rodziny. Jakie są zatem elementy prawa tożsamość rodziny? Są to: prawo do wychowania dzieci według własnych przekonań i zgodnie z kulturą i zwyczajami rodziny, prawo rodziny do poszanowania jej integralności, prawo rodziny do wyboru własnej tożsamości etnicznej i kulturowej oraz prawo rodziny do wyboru własnej przynależności narodowej, języka i religii. Pomimo iż rodzina na ogół cieszy się tymi prawami, nigdzie nie są jej one przyznane wprost, w oderwaniu od przynależności grupowej. Prawem rodziny powinno być zatem prawo wyboru tej przynależności i określenia swojej własnej niepowtarzalnej tożsamości. Słusznie podkreśla George Stewart, że brak nałożenia na państwo obowiązku ochrony tożsamości rodziny czyni rodzinę bardziej narażoną na niebezpieczeństwo i bezradną wobec zagrożeń, jakie niesie obecny świat. Dziś bowiem rodzina wymaga specjalnej ochrony, która jest obowiązkiem państwa.

\section{Bibliografia}

Anderson O'Gorman B. R., Imagined Communities: Reflections on the Origin and Spread of Nationalism, London 2006.

A.J. Bellami, The Formation of Croatian National Identity: A Centuries-old Dream?, Manchester 2003, New York: Manchester University, http:// www.jstor.org/stable/j.ctt155jgdc (24.09.2020).

Brubaker R., Ethnicity without Groups, Cambridge 2004.

Coulmas F., Identity: A Very Short Introduction, Oxford 2019.

Hobsbawm E. J., Nations and Nationalism Since 1780: Programme, Myth, Reality, Cambridge 2012.

Kuźnicka D., Prawo do tożsamości jako prawo dziecka - wybrane zagadnienia, „Folia Iuridica Universitatis Wratislaviensis” (2016), vol 5 (2), s. 181.

Gruen E. S., Introduction, w: Cultural Identity in Ancient Mediterranean, ed. E. S. Gruen, Los Angeles 2011.

Roagna I., Ochrona praw do poszanowania życia prywatnego w Europejskiej Konwencji o Ochronie Praw Człowieka, Strasburg 2012. 
Stewart G., Interpreting the Child's Right to Identity in the U.N. Convention on the Rights of the Child, „Family Law Quarterly” 3 (1992) 26, s. 221-233, www.jstor.org/stable/25739908 (04.06.2020).

Tożsamość, w: Słownik języka polskiego PWN, https://sjp.pwn.pl/sjp/ to\%C5\%BCsamo\%C5\%9B\%C4\%87;2530211 (04.06.2020).

\section{Ustawy}

Konstytucja Rzeczypospolitej Polskiej z dnia 2 kwietnia 1997 r., Dz. U. z 1997, poz. 78, nr 483.

Konwencja o prawach dziecka przyjęta przez Zgromadzenie Ogólne Narodów Zjednoczonych dnia 20 listopada 1989 r., Dz. U. z 1991, poz. 120, nr 526.

Konwencja o ochronie praw człowieka i podstawowych wolności sporządzona w Rzymie dnia 4 listopada 1950 r., zmieniona następnie Protokołami nr 3, 5 i 8 oraz uzupełniona Protokołem nr 2, Dz. U. z 1993, poz. 61, nr 284.

Międzynarodowego Paktu Praw Obywatelskich i Politycznych, Dz U. 1977, nr 38, poz. 167.

Ustawa z dnia 6 stycznia 2005 r. o mniejszościach narodowych $i$ etnicznych oraz o języku regionalnym, Dz. U. z 2017, nr 823, t.j. 